\title{
Etna lavas are melts leaking from the low velocity zone
}

\author{
Pilet S. ${ }^{1}$, Reymond J. ${ }^{1}$, Chiaradia M. ${ }^{2}$ \& Corsaro \\ $\mathrm{R}^{3}$ \\ ${ }^{1}$ University of Lausanne, CH. Sebastien.Pilet@unil.ch \\ ${ }^{2}$ University of Geneva, CH. Massimo.Chiaradia@unige.ch \\ ${ }^{3}$ INGV Catania, IT. rosanna.corsaro@ingv.it
}

Etna is an unusual volcano in terms of geological setting, effusion rate and volatile content. Etna is closely related to the subduction of the Ionian plate below Eurasia, but, chemically, Etna lavas are akin to intraplate magmatism, despite the lack of evidence for any mantle plume activity around Sicily. The sequence of magma emission at Etna differs from typical oceanic islands such as Hawaii, with the initial emission of small volumes of tholeiitic lava followed by a shift to alkaline composition associated with a significant increase of effusion rates. Current models suggest that magma generation is linked to mantle upwelling associated with the differential roll back of the Ionian slab. Here, we rather suggest that Etna and associated Hyblean plateau volcanism are low-degree melts extracted from the low velocity zone (LVZ) in response to lithospheric stress. Geophysical studies suggest the presence of low degree melts at the base of the oceanic lithosphere to explain the seismic and electric properties of the LVZ. The characteristics of Etna lavas emitted today (high $\mathrm{H}_{2} \mathrm{O}$ and $\mathrm{CO}_{2}$ content, high $\mathrm{K}_{2} \mathrm{O} / \mathrm{Na}_{2} \mathrm{O}$ ratio, but low $\mathrm{TiO}_{2}$ content compared to typical oceanic islands magmas) as well as an isotopic composition similar to E-DMM are compatible with extremely low degree peridotitic melts $(<0.2 \%)$ accumulated at the base of the lithosphere. The small volume of tholeiites emitted during the early stage of Etna activity is explained by the reaction of alkaline melt from the LVZ with the lithospheric mantle. Opx dissolution associated with melt-peridotite reaction shifts lava composition from alkaline to tholeiitic, and produces dunite channels, which are used, subsequently, to extract alkaline melt from the LVZ to the surface without significant interaction with the lithospheric mantle. The formation of Hyblean plateau lavas, 2 to $8 \mathrm{Myr}$ ago, requires the interaction of low degree melts extracted from the LVZ in response of plate flexure with metasomatic lithosphere in a similar way to that described for Petit-spot magmas observed in front of Japan.

Etna may not require mantle upwelling, but could simply represent the extraction of melt preexisting at the base of the lithosphere in response to the specific tectonic setting observed around Sicily. This model explains the temporal, compositional and volumetric evolution of the Etna lavas. 